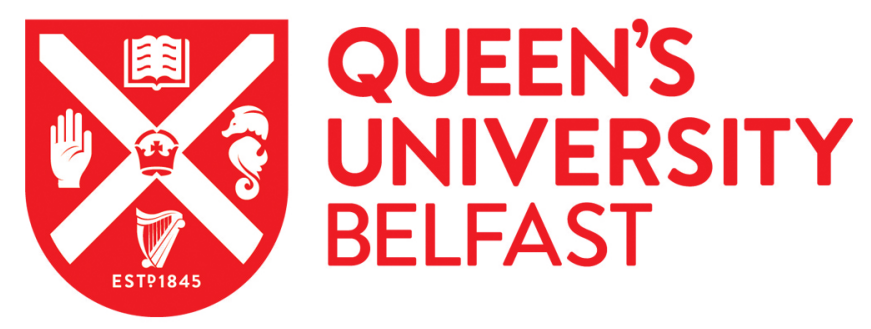

\title{
Spatial and temporal differences in gonad development, sex ratios and reproductive output influence the sustainability of exploited populations of the European oyster, Ostrea edulis
}

Eagling, L., Ashton, E., Jensen, A., Sigwart, J., Murray, D., \& Roberts, D. (2017). Spatial and temporal differences in gonad development, sex ratios and reproductive output influence the sustainability of exploited populations of the European oyster, Ostrea edulis. Aquatic Conservation Marine and Freshwater Ecosystems, 112. https://doi.org/10.1002/aqc.2855

Published in:

Aquatic Conservation Marine and Freshwater Ecosystems

Document Version:

Peer reviewed version

Queen's University Belfast - Research Portal:

Link to publication record in Queen's University Belfast Research Portal

\footnotetext{
Publisher rights

Copyright 2017 John Wiley \& Sons. This work is made available online in accordance with the publisher's policies. Please refer to any applicable terms of use of the publisher.
}

\section{General rights}

Copyright for the publications made accessible via the Queen's University Belfast Research Portal is retained by the author(s) and / or other copyright owners and it is a condition of accessing these publications that users recognise and abide by the legal requirements associated with these rights.

Take down policy

The Research Portal is Queen's institutional repository that provides access to Queen's research output. Every effort has been made to ensure that content in the Research Portal does not infringe any person's rights, or applicable UK laws. If you discover content in the Research Portal that you believe breaches copyright or violates any law, please contact openaccess@qub.ac.uk. 
1 Spatial and temporal differences in gonad development, sex ratios and reproductive output,

2 influence the sustainability of exploited populations of the European oyster, Ostrea edulis

3 Eagling, L. E. ${ }^{1 *}$, Ashton, E. C. ${ }^{1}$, Jensen, A. C. ${ }^{2}$, Sigwart, J. $^{1}$, Murray, D. ${ }^{3}$, and Roberts, D $^{1,3}$.

$4{ }^{1}$ Queen's University Belfast Marine Laboratory, 12-13 The Strand, Portaferry BT22 1PF, Co. Down,

$5 \quad$ Northern Ireland, UK

$6{ }^{2}$ Ocean and Earth Science, National Oceanography Centre Southampton, University of

7 Southampton Waterfront Campus, European Way, Southampton, SO14 3ZH, United Kingdom

$8{ }^{3}$ Queen's University Belfast, Medical Biology Centre, Lisburn Road, Belfast, Northern Ireland, BT9

$97 \mathrm{AE}$

*leagling01@qub.ac.uk

\section{Abstract}

1. The European native oyster, Ostrea edulis, has been in severe decline since the early 1900s across Europe with many fisheries now declared commercially extinct. In light of this broad scale population decline, the UK has listed O. edulis as a threatened species, requiring conservation action under the Biodiversity Action Plan (BAP). In addition to this designation, in Scotland O. edulis beds are search features (SF) and priority marine features (PMF) for MPA site selection. These sites are also listed as a feature of conservation importance and included on the OSPAR list of threatened/declining species and habitats.

2. Recent studies have identified $O$. edulis populations with heavily male-skewed sex ratios, which may have contributed to fisheries decline due to reduced levels of fertilisation. This species is a protandrous alternating hermaphrodite and individuals may change sex in response to local conditions. This study aimed to assess how sex ratios vary temporally 
and if this is correlated with temperature, by studying two exploited populations in Loch Ryan, Scotland and Chichester Harbour, England.

3. This study suggests that the proportion of male phase oysters is positively correlated with water temperature and that the study population in cooler waters had a more balanced sex ratio overall (the Loch Ryan population was significantly similar to 1:1 for 10 of 13 months, whereas in Chichester only 1 of the 7 months was significantly similar).

4. This study provides evidence to suggest that a critical temperature threshold for sex determination exists in $O$. edulis and for the Loch Ryan population we suggest that this is $16.5^{\circ} \mathrm{C}$. However, further work is required to assess how this threshold may change between sites and how future climate change scenarios might affect the sex ratio of native oyster populations.

\section{Keywords}

Aquaculture, Climate change, Coastal, Invertebrates, Reproduction, Restoration, Sea loch

\section{Introduction}

Native oyster populations, which historically dominated many coastal and estuarine ecosystems, have been driven globally to the brink of functional extinction by overexploitation (Beck et al., 2011). Populations of oysters, such as the European oyster Ostrea edulis (Linnaeus), continue to be harvested unsustainably due to adherence to traditional methods of exploitation (Beck et al., 2011) and a failure to apply understanding of the biology of the species to its management. Due to the decline of $O$. edulis it is now listed as a UK Biodiversity Action Plan (BAP) species, to be maintained and expanded (UKBG, 1999), and is included on the OSPAR list of species and habitats that were threatened and/or declining in 2003 (OSPAR, 2009). Within Scotland, O. edulis beds are priority marine features (PMF) and search features (SF) for MPA site selection. Since this species 
remains important to fisheries around the UK, conservation aims need to sustain local populations whilst maintaining economically viable fisheries (Lane \& Stephenson, 1995). Loch Ryan contains two sites of Special Scientific Interest (SSIs) due to geological interest (Mather, 2003) and in 1990 the whole loch was designated as a Marine Consultation Area (MCA) by Scottish Natural Heritage (SNH), highlighting it as an area distinct for the sensitivity and quality of its marine environment (Golding, Alman \& Service, 2001; Loch Ryan Advisory Management Forum, 1999). Chichester Harbour is situated within an Area of Outstanding Natural Beauty (AONB) and is a site of Special Scientific Interest (SSI) partly due to the vital areas for overwintering birds.

Ostrea edulis is a protandrous alternating hermaphrodite (Orton, 1937) which first reproduce as a male on reaching sexual maturity and thereafter alternates between sexes. The male gametes are released into the water column and drawn into the female mantle cavity via the inhalant siphon, where the eggs are fertilised (Walne, 1974) and brooded for 6-8 days (Helm \& Bourne, 2004). The process of sex change and the controls for sex alternation are not precisely known for $O$. edulis (Kamphausen, Jensen, \& Hawkins, 2011); however, like most bivalve species it is understood to be largely controlled by neuropeptides and steroids (Morishita, Furukawa, Matsushima, \& Minakata, 2010). This change in sex, or serial development of gonads in alternating sexes, occurs repeatedly throughout the lifetime of an individual and may take place several times within a single summer breeding season (Walne, 1974). Thus, the sex ratio in a population could fluctuate significantly during the breeding period with individuals reproducing as both male and female in a single season. Despite this fluctuation within a population it is suggested that the overall sex ratio should conform to a 1:1 ratio (Kamphausen et al., 2011); however, male biased ratios are frequently reported (e. g. Bourne, 1890; Cole, 1939; Kamphausen et al., 2011). Skewed sex ratios can lead to inbreeding, limited fecundity, and, coupled with exploitation, rapidly result in severe population declines. 
Temperature is known to have a major effect on reproduction in 0 . edulis directly by determining the start and end of the breeding period and gametogenic progression, and indirectly by regulating sex changes (Joyce, Holthuis, Charrier, \& Lindegarth, 2013). Non-native oyster species in Europe have had increasing reproductive success since the 1960s partly due to increasing sea surface temperatures (Thomas et al., 2015) and the response of native species to the same environmental drivers is therefore important to predict potential competitive interactions. Most previous research to assess the impacts of temperature on sex ratios and gametogenesis in oysters has been based in laboratory or hatchery settings (Joyce et al., 2013; Mann, 1979). In a long-term laboratory study of reproduction in 0 . edulis, a female-dominated group in cooler temperatures shifted to become a male-dominated group after exposure to gradually increasing temperature conditions, indicating that there is perhaps a direct correlation to temperature rather than a simple seasonal phenology in sex changes (Joyce et al., 2013). In the present study, we aim to assess how temperature affects sex ratio and fecundity in populations of $O$. edulis under natural conditions and fisheries pressures in order to aid conservation efforts and develop sustainable fisheries. We predicted that wild populations of $O$. edulis would show similar temperature-based changes in sex ratios, with cooler spring temperatures early in the breeding season correlated with a female bias and more female oysters brooding, and warmer water temperatures in late summer and autumn leading to a male bias with fewer female oysters brooding.

To explore this potential temperature driven change in sex ratios, this study aimed to explore two relevant case studies of exploited $O$. edulis populations that span a wide latitudinal range in the UK, and which are exposed to differing temperature regimes. The two populations are located in Loch Ryan, Scotland, which was studied in the 1960s and 2012-2015 (and from now on will be referred to as LR), and Chichester Harbour, England which was studied for one year in 2011 (and from now on will be referred to as $\mathrm{CH}$ ). We acknowledge that there are some limitations associated with comparing the one year study of $\mathrm{CH}$ with the more extensive studies of $\mathrm{LR}$, 
particularly since these investigations were not run concurrently. However, comparison of the reproductive potential of these populations provides a context to consider how temperature might affect reproductive output of oyster fisheries providing information for the sustainable management and conservation of this species.

\section{Materials and Methods}

\subsection{Study sites}

Loch Ryan, Southwest Scotland $\left(54.9506^{\circ} \mathrm{N}\right)$ (Figure 1) makes an interesting case study because it has fewer stressors in comparison to the fisheries on the south coast of England. Loch Ryan has no diseases (such as bonamiasis) present, limited boat traffic, a low fishing effort and reduced anthropogenic waste input. Loch Ryan is one of the last remaining wild European oyster fisheries in the United Kingdom that has survived long term 'boom and bust' cycles due to its unique private ownership over the last 300 years (Eagling, Ashton, \& Eagle, 2015). The fishery in Loch Ryan was studied extensively during a closed period $(1957-1970)$ by Millar $(1963,1964)$ which are examined and discussed in this study. In comparison, Chichester Harbour $\left(50.8056^{\circ} \mathrm{N}\right)$ in Southeast England, is known to contain diseases such as bonamiasis, and the area is subject to heavy commercial shipping and recreational boat traffic. In the year prior to the oyster sampling in Chichester Harbour, the oysters were concentrated from across the harbour into broodstock beds to increase the density from approximately one oyster per $\mathrm{m}^{2}$ to 40 oysters per $\mathrm{m}^{2}$ (Eagling, 2012; Eagling \& Jensen, 2012).

\subsection{Sampling}

In LR, oysters were sampled $(n=20)$ every two weeks from April through to mid-October in both 2013 (260 oysters collected in total) and 2014 ( 240 oysters collected in total), to compare inter and intra-annual differences within the breeding season. The oysters were collected using a $1.8 \mathrm{~m}$ 
dredge towed at speeds of less than 2 knots by the $37 \mathrm{ft}$ fishing vessel 'Vital Spark'. In $\mathrm{CH}$, sampling occurred every 2-3 weeks from April to October in 2011, using a small Van Veen Grab which enabled a total collection of 212 oysters. In the laboratory, all samples (across both sites) were first weighed wet (shell and flesh), the shell height measured with calipers, and then either dissected immediately or the shells were broken and oysters fixed and stored in $4 \%$ borax buffered formalin. When dissected, the gonad was removed and cut into two or three pieces approximately $4 \mathrm{~mm}$ thick. The tissue was dehydrated through a series of increasing ethanol concentrations (30, 50, 70, 90, 95 and 100\%) (Meneghetti, Moschino, \& Da Ros, 2004) and finally washed with Histoclear. The tissue was mounted in paraffin wax (Delgado \& Pérez-Camacho, 2007) and sectioned using a Leica RM2255 microtome at 7 - $9 \mu \mathrm{m}$ thickness throughout the sample. Multiple slides were created for each oyster with several sections on each to ensure a clear section of the gonad. The slides were stained using an adapted Haematoxylin and Eosin procedure (Howard \& Smith, 1983) to identify the gametic cells within the tissue and examined using a light microscope (Olympus BX41). The sex (predominantly in either the male or female phase, see Figure 2) and stage of gametogenic development were determined for each oyster. Gametogenic stages were scored according to the classification schemes devised by Wilson \& Simons (1985) and Loosanoff (1962) where gonads were categorised into seven stages (gonad index) as in early or late development, early maturation, ripe, partially spent, spent or inactive.

The water temperature of LR was recorded every ten minutes using a Hoboware temperature logger securely tied to a creel next to the oyster beds at approximately $5 \mathrm{~m}$ depth and retrieved monthly to download the data. Temperature at $\mathrm{CH}$ was taken from a probe on the Camber Pile weather station, based about 2 nautical miles from the sampling location (accessed online from: cambermet.co.uk), just below the water surface. A temperature probe was used on four occasions to measure the temperature offset between the weather station pile and the oyster sampling location (3-5 $\mathrm{m}$ below the surface) and the dataset calibrated accordingly. 
All statistical analyses were carried out in R Studio (version 0.99 .903 and $R$ version 3.3.1) ( $R$ Core Team, 2015), where the monthly sex ratio of the Loch Ryan population was compared to the suggested 'ideal' ratio of 1:1 using Chi squared tests, due to the multiple tests carried out within the hypothesis the $\mathrm{p}$ value was corrected using the Bonferroni correction. The annual sex ratio for 2013 and 2014 were also compared to a 1:1 ratio using Chi squared and then the 2013 ratio with the 2014 ratio. The sex ratio over both years was pooled for the Loch Ryan site and compared to other previously assessed populations in LR (1960/61) (Millar, 1963; 1964), CH (2011), Southampton, England (Kamphausen et al., 2011) and a Greek cohort (da Silva, Fuentes \& Villalba, 2009).

Inter-annual temperature variation in LR was assessed using an ANOVA, and to consider the differences in brooding percentages between LR 2013 and 2014, and between LR 2013 and CH 2011, Wilcoxon tests were used. The relationship between temperature and a) sex ratio, b) brooding percentage and c) larvae per brood, and percentage males to percentage brooding females were assessed using linear regressions.

\section{Results}

\subsection{Temperature patterns at study sites}

Water temperatures in LR ranged from $1.8^{\circ} \mathrm{C}$ in February 1960 to $18.6^{\circ} \mathrm{C}$ in June 1960 (Millar, 1963), and from $4.5^{\circ} \mathrm{C}$ in March 2013 to $18.1^{\circ} \mathrm{C}$ in July 2014 during fieldwork within the present study. Temperatures within the loch were higher from July through to January in 2013/14 than 50 years previously, but were colder between February and June although there was no significant difference among the temperatures of each year (ANOVA, $f=0.64$, d.f. $=59, p>0.05$ ) (Figure 3). 
consistently above $16^{\circ} \mathrm{C}$ from June until mid-October only in $\mathrm{CH}$ and average temperatures also exceeded $18^{\circ} \mathrm{C}$ for 27 days in $\mathrm{CH}$ compared to 1 day in LR (2013/14).

\subsection{Gonad development}

Gametogenic changes in O. edulis during the breeding period (April to October) in LR showed similar patterns in both 2013 and 2014 with spawning, as evidenced by the proportion of partially and fully spent individuals, extending from June to October in both years (Figure 4). However, spawning appeared to be more advanced in 2013 when more than $40 \%$ of oysters were spawning compared to approximately 20\% in June 2014 (Figure 4). In CH, individuals were identified spawning from May and a greater proportion were spent from August onwards compared to both years in LR. As the temperature and season progressed, the gonad index increased until September in LR and in $\mathrm{CH}$ a decrease was not observed within the sampling period (up to the end of October) (Figure 4).

\subsection{Sex Ratios}

The proportion of males across both sites exceeded $50 \%$ on 19 out of 23 sampling occasions in LR and exceeded $60 \%$ in all samples from $\mathrm{CH}$ (Figure 5). However, for the majority of months between 2013 and 2014 in LR the sex ratio was not statistically significantly different from a ratio of 1:1. For a few months each year (June 2013 and May, August, September 2014) the ratio was so heavily skewed towards a male population, that the pooled annual ratio became skewed (Table 1). Of the oysters sampled from LR in 2013, 87 displayed predominantly male characteristics and 54 female characteristics, whilst the rest were characterised as spent. This resulted in an overall 3 male: 2 female ratio among unspent animals, which differed significantly from parity (Table 1). Similarly, the sex ratio in 2014 (2 male:1 female) showed a significant departure from parity (Table 1) with 129 oysters displaying predominantly male characteristics, 58 displaying predominantly female characteristics and the remaining oysters characterised as 
spent. By contrast in the 1960/61 period in LR (Millar, 1964) 9 months were significantly skewed from the 1:1 ratio (compared to the four months over 2013/14), with the greatest difference occurring in the middle of August 1961, with a ratio of 7 male: 1 female (Table 2).

Although there were four months recorded where the number of females exceeded the number of males, (September 2013, April and June 2014, and December 1960) this was not consistent between the years and so was not investigated further. When the LR 2013/14 ratios were compared between years, there was no significant difference $\left(x^{2}=1.9\right.$, d.f. $\left.=1, p>0.05\right)$ and therefore the two years were grouped for comparison to other populations (Table 3).

The average percent of the oyster population brooding over the breeding period (April to October) ranged from $6 \%$ (15\% of females) $(\mathrm{CH}, 2011)$ to $18 \%$ (30\% of females) (LR, 2013) (Figure 6). There was a significant difference between the percentage of brooding oysters recorded in LR 2013 and CH 2011 (Wilcoxon test $w=1, p<0.05$ ), and in LR in 2013 and 2014 (Wilcoxon test $w=25$. $5, \mathrm{p}<0.05$ ) (Figure 6). The proportion of oysters brooding varied in $\mathrm{CH}$ between 3 and $10 \%$, and in LR between 3 and 25\% in 1960/61, and 5 and 25\% in 2013/14 (Figure 6). Peak brooding appeared to occur around the beginning of July; a second smaller peak in brooding was identified towards the end of August in LR.

\subsection{Relationships between temperature, sex ratios and reproductive output}

The proportion of male oysters pooled across all sites and years showed a significant positive linear relationship with temperature (Figure 7A) $\left(R^{2}=0.467\right.$ and $\left.p<0.05\right)$. There was no significant relationship between the percentage of females brooding and temperature (Figure 7B) (linear regression, $p>0.05$ ); however, visual inspection of these patterns suggests that the optimum temperature for brooding may be around $16.5^{\circ} \mathrm{C}$ for the $L R$ population and $17.5^{\circ} \mathrm{C}$ for the $\mathrm{CH}$ population. The data recorded may also reflect two spawning periods within the 
population: one at the beginning of the brooding season with a higher percentage of brooding females and then a second smaller spawning event later in the summer. When considering the abundance of larvae per oyster brood (Figure 7C), there was an apparent negative correlation with average daily sea temperature, but this was not significant $\left(R^{2}=0.376, p=0.1\right)$. There was no correlation between the percentage of females brooding and the percentage of male oysters (Figure 7D).

\section{Discussion}

\subsection{Gametogenic progression}

Although many studies have examined gametogenic progression in marine bivalves, including various species of oysters, these mostly focus on the influence of environmental factors or latitudinal gradients (Ruiz et al., 1992). Here we provide new insight into the inter-relationships between temperature, sex ratio, the number of brooding individuals and gametogenesis within $O$. edulis. We confirm that gametogenesis occurred throughout the summer periods, with no signs of reabsorption, suggesting that conditions in both locations monitored were suitable for oyster growth and reproduction (Kamphausen et al., 2011). The combined results from both populations suggest that higher temperatures promote further developed stages of gametogenesis, with the greatest proportion of ripe and spent oysters in both sexes observed earliest in 2011 (CH), followed by 2014 (LR) and then 2013 (LR), which corresponds with the order of average temperatures over those summer periods from the highest (2011) to lowest (2013). Temperature therefore appears to be a key driver of gametogenic progression within O. edulis in wild populations, as well as in experimental set ups (Joyce et al., 2013). This is in contrast to the apparent seasonal synchrony in spawning over broadly separated populations observed in the non-native oyster Crassostrea gigas in Europe (Philippart et al., 2012). When temperature falls 
below a threshold value during late autumn, 0 . edulis gonads appear to enter an over-wintering inactive stage; however, if this threshold is not reached, such as in southern Spain, the gametogenic cycle is not interrupted (Ruiz et al., 1992).

\subsection{Sex ratios}

Previous research predicted sex ratios of 1:1 (male: female) in O. edulis populations (Kamphausen et al., 2011; University Marine Biological Station Millport, 2007), but it is not clear whether that is realistic or stable in healthy natural populations. Ostrea edulis is an alternating hermaphrodite and therefore sex changes can occur frequently during the breeding period, resulting in potentially fluctuating sex ratios across the population (Walne, 1974). Interestingly, within this study, only $2.5 \%$ of oysters (12 individuals of 480 sampled in $2013 / 14$ ) were sampled mid-change between the sexes, suggesting that alternation occurs rapidly and there is no intermediate simultaneous hermaphroditic condition or that the alternation occurs infrequently. The high percentage of brooding oysters in LR indicates favourable conditions for $O$. edulis and could support rapid alternation but further research is required in the laboratory to determine this.

There are extensive data already established for the observed sex ratios of $O$. edulis in the waters of Britain and Ireland, though frequently individual point measurements of sex ratios have been taken to represent the long-term male/female bias in a population, for example sex parity within populations has only been recorded during specific periods of the year (Millar, 1964) or in aquarium conditions (Cole, 1939; Mann, 1979). The majority of natural studies indicated a maleskewed ratio of 1.5:1 in cultivated oysters (Bourne, 1890) or between 1.2:1 (Bourne, 1890) and up to 3:1 in natural populations (Cole, 1942; Millar, 1964). More recent investigations found strongly male-dominated populations in a Greek cohort (3:1) (da Silva et al., 2009) and Southampton (6:1) (Kamphausen et al., 2011). The pooled annual sex ratio of males to females in LR was 1.9:1 in 1960, 2.2:1 in 1961 (Millar, 1964), 1.5:1 in 2013 and 2:1 in 2014. Millar (1964) found that malephase oysters outnumbered female-phase oysters throughout the breeding season in 1960 and 
1961. By contrast, although the pooled annual sex ratio in LR was male-biased in both 2013 and 2014, the population maintained a sex ratio which did not depart significantly from parity for most of the time (10 of the 13 months sampled during this period). In $\mathrm{CH}$, where the pooled annual sex ratio was 3:1, sex ratios were consistently more skewed than 2:1 throughout 2011. These results suggest that the LR population is less skewed and significantly different from the other populations, such as those studied in Southampton (Kamphausen et al., 2011), Chichester and a Greek cohort (da Silva et al., 2009) (Table 3).

The sex ratio of a population is vital to ensure breeding success but the impact of a skewed ratio is also dependent on population density and subsequent larval settlement and survival. For example, oysters in a healthy reef are typically densely aggregated, therefore a predominance of males would have a reduced impact on reproductive output because, although there are fewer females, these are highly likely to be fertilised and produce larvae as a consequence of their close proximity to males and an increased substrate for larval settlement and survival. Although a predominance of males could compensate for sperm dilution in populations that have low densities, we found no significant relationship between the proportions of males and brooding females (Figure 7D). So in wild populations under fisheries stress, a male-skewed sex ratio does not appear to be an effective compensatory response.

\subsection{Brooding}

Ostrea edulis differs from most other oyster species such as Crassostrea spp., where ample phenology information is available, by being a larviparous brooder. The proportion of brooding females in a population is a useful measure of reproductive output in 0 . edulis, particularly when supported by data on brood size. The overall percentages of brooding oysters in LR ( $20 \%$ in 2013 and $8 \%$ in 2014), were consistently higher than other recently documented UK rates and, according to Walne (1974), within the suggested range for healthy populations. In comparison, only $6.1 \%$ of oysters (translocated from LR) sampled in 2014 in Mumbles Bay, Wales were found 

proportion of the population brooding has been $<8 \%$ over the past three years (Bromley, 2015). However, the proportion of oysters brooding was low in comparison with historical reports from other sites such as West Mersea, Essex (45\%) and the Fal Estuary, Cornwall (44\%) (Orton, 1927) and showed inter-site and inter-year differences. Although recording the proportion of brooding individuals within a population provides a useful baseline for measuring reproductive success, we suggest this should be combined with sex ratio data in order to assess what percentage of the female population is brooding. To illustrate how this could provide greater insight into population viability, we can consider a theoretical oyster population of 90 individuals where $10 \%$ of the population are known to be brooding. This appears to be a relatively low value, however, if we then discover that the sex ratio is 1:8 (10 females and 80 males), this represents successful fertilisation of $90 \%$ of females within the population. With the benefits of such insight, appropriate strategies can be developed to aid sustainable management of populations.

\subsection{Factors affecting sex ratio}

The sex ratio within a population may also skew seasonally in relation to local environmental conditions, with a particular sensitivity to water temperature. This has been noted in many ostreid species, such as $C$. gigas where sex determination is strongly influenced by temperature with a genetic component facilitating male skewed ratios at high temperatures (Santerre et al., 2013). In our study, significantly male skewed sex ratios were observed in LR, following a temperature spike. Previous studies also found that temperature has an effect on sex ratios in both O. edulis and C. gigas (Joyce et al., 2013; Mann, 1979; Santerre et al., 2013) with more females observed during periods of lower temperatures. Post spawning oysters predominantly observed as male may relate to low metabolic reserves. Mann (1979) found that when O. edulis were kept at $18^{\circ} \mathrm{C}$ or above, the sex ratio was significantly skewed towards males. Millar (1963, 1964) also found the most male skewed ratios in LR occurred when the water temperature was 
over $16^{\circ} \mathrm{C}$ (Figure 5). These previous findings support evidence from this study that 0 . edulis populations may have a critical temperature threshold for sex determination. Higher temperatures were observed in Chichester Harbour, England where the sex ratio was consistently more skewed than 2:1 and similar temperatures were observed in Southampton where the sex ratio was observed to be 6:1 (Kamphausen et al., 2011). The significant increase in the proportion of males with increasing temperature, demonstrated by the present study, supports a strong temperature component in sex determination. This temperature effect may also explain the decline in the proportion of female-phase oysters in LR during the 1960s (Millar, 1964), where temperatures were warmer in the build up to summer. This decline was not evident in LR in the more recent study, although there is an indication of increasing proportions of females towards the end of the breeding period (Figure 5) and also in $\mathrm{CH}$ as temperatures declined.

Alongside the relatively well documented effects of temperature on oyster sex ratios (Mann, 1979; Santerre et al., 2013), there are other factors that may influence the sex ratio in O. edulis. These include endocrine disrupting chemicals (ECDs), such as tributyltin (TBT) (Kamphausen et al., 2011; Park et al., 2012; Thain \& Waldock, 1986) or stress which could be induced by disease (da Silva et al., 2009), shell damage (Bahr \& Hillman, 1967; Davis \& Hillman, 1971; Ford \& Figueras, 1988), and limited food availability (Kennedy, 1983). Since the most common disease known to affect $O$. edulis is bonamiasis (Culloty and Mulcahy, 1996), caused by the protozoan parasite Bonamia ostreae has not yet reached the LR population (Hugh-Jones, 2011) and pollution and other stressors are thought to be low at LR, temperature is considered to be a main influencer on the sex ratio here. This study site can provide a baseline for the restoration of other healthy UK sites to sustainable levels.

The sustainability of exploited oyster populations is itself dependent on many factors including broodstock density, fertilisation success, and the subsequent larval settlement and survival. The sex ratio of populations play an important role in their long-term sustainability, although these 
impacts will vary significantly depending on the population dynamics and factors such as broodstock density, fertilisation success, and the subsequent larval settlement and survival. A strongly biased sex ratio within dispersed populations, such as those in the Solent, England have led to these fishing beds being temporarily closed to fishing due to low oyster density (Southern IFCA pers. comm., 2016). Broodstock density itself is also influenced by fishing pressure, disease (Cochennec, Le Roux, Berthe, \& Gerard, 2000) and environmental stress, such as atypically cold winters (Orton, 1940). Furthermore, any larvae produced must survive to settlement, dependent on predation, the availability of food and suitable settlement substrata. Through active management, the sustainability of populations can be improved e.g. through restocking, relaying beds (Eagling, 2015), relaying shell (cultch) to provide suitable substrate for larval settlement and management of fishing pressures (Eagling et al., 2015). The sex ratio in LR was skewed but the population appears to be sufficiently densely laid to maintain a high percentage of brooding cannot be controlled.

\section{Conclusions}

Life-history theory attempts to predict the relative influences of density-dependent and independent influences on life cycles and population dynamics (Winemillar, 2005). Although density-dependent factors are likely to be the major cause of the decline and collapse of many fisheries, including those for oysters (Kamphausen, 2012; Laing, Walker, \& Areal, 2005), here we propose that such effects will be exacerbated by density-independent factors, such as temperature. Under predicted climate change scenarios, the shelf sea temperature around the UK is projected to increase by $1.5<4^{\circ} \mathrm{C}$ by the end of the $21^{\text {st }}$ century (Jenkins et al., 2010). From the results of this study we suggest that initially, small increases in temperature may create a 
longer viable brooding period for $O$. edulis; however, when sea temperatures exceed $16.5^{\circ} \mathrm{C}$ in $\mathrm{LR}$, the percentage of brooding females declined. This may represent a critical temperature threshold for sex determination, however this may vary between sites and further work will be required to assess how future climate change scenarios may affect the sex ratio of $O$. edulis populations. We recommend that future conservation efforts should be concentrated on creating refuge populations, particularly within MPAs where $O$. edulis are priority marine features for MPA site selection within Scotland. With careful site selection for refuge populations at cooler climes, it may be possible to build long-term, sustainable populations in case of higher water temperatures under extreme climate change scenarios.

\section{Acknowledgements}

The authors wish to particularly acknowledge the contributions of Dr Dai Roberts, who passed away shortly after this paper was accepted and we would like to dedicate this paper to his memory. A great scientist and mentor whose guidance and kind words will be much missed.

We sincerely thank the Wallace and Hugh-Jones families for their support during this work and providing access to the fishery and we are very grateful to the fishermen of The Vital Spark Rob Lamont and John Mills for their constant assistance in the field and boat time. Sampling in Chichester harbour was facilitated by Sussex IFCA, CHOPI and the Chichester Harbour conservancy. This research was funded by IBIS, project 2859 supported by the European Union's INTERREG IVA Programme managed by the Special EU Programmes Body (www.seupb.eu). Our thanks go to the staff of the Queen's University Marine Laboratory (QML) and Natasha Phillips, Lauren Sumner-Rooney, Brendan McNamara, Emma Gorman, Fergal Glynn, Laura Hinchliff, Siobhan Vye, Luke Murphy and Rachel O'Malley for their help in both the field and laboratory. 
Bahr, L. M., \& Hillman, R. E., (1967). Effects of repeated shell damage on gametogenesis in the American oyster, Crassostrea virginica, (Gmelin), Proceedings of the National Shellfish Association, 57, 59-62.

Beck, M., Brumbaugh, R., Airoldi, L., Carranza, A., Coen, L., Crawford, C., Defeo, O., Edgar, G., Hancock, B., Kay, M., Lenihan, H., Luckenbach, M., Toropova, C., Zhang, G., \& Guo, X. (2011) Oyster Reefs at Risk and Recommendations for Conservation, Restoration, and Management, Bioscience, 61, 107-116.

Bourne, G. C. (1890) The generative organs of the oyster. Journal of the Marine Biological Association of the United Kingdom, 1, 268-281.

Bromley, C. A. (2015) Science-based management strategies for the commercial and environmental sustainability of the European oyster, Ostrea edulis L. PhD Thesis. The Queen's University of Belfast 226pp

Cochennec, N., Le Roux, F., Berthe, F., \& Gerard, A. (2000) Detection of Bonamia ostreae based on small subunit ribosomal probe, Journal of Invertebrate Pathology, 76, 26-32.

Cole, H. A. (1939) Further experiments in the breeding of oysters (Ostrea edulis) in tanks, Ministry of Agriculture and Fisheries, Fisheries Investigation, Series II, 16, 1-47.

Cole, H. A. (1942) The American whelk tingle, Urosalpinx cinerea (Say), on British oyster beds. Journal of the Marine Biological Association of the United Kingdom, 25, 477-508.

Culloty, S. C., \& Mulcahy, M. F. (1996) Season-,age-, and sex-related variation in the prevalence of bonamiasis in flat oysters (Ostrea edulis L. ) on the southern coast of Ireland, Aquaculture, $144,53-63$. 
da Silva, P. M., Fuentes, J., \& Villalba, A. (2009) Differences in gametogenic cycle among strains of the European flat oyster Ostrea edulis and relationship between gametogenesis and bonamiosis, Aquaculture, 287, 253-265.

Davis, N. W., \& Hillman, R. E. (1971) Effect of artificial shell damage on sex determination in oysters (Abstract), Proceedings of the National Shellfish Association, 61, 2.

Delgado, M., \& Pérez-Camacho, A. (2007) Comparative study of gonadal development of Ruditapes philippinarum (Adams and Reeve) and Ruditapes decussatus (L. )(Mollusca: Bivalvia): Influence of temperature. Scientia Marina, 71, 471-484.

Eagling, L. E. (2012) Reproductive success of the re-laid native oyster Ostrea edulis in Chichester harbour. MSci dissertation, University of Southampton. $60 \mathrm{pp}$

Eagling, L. \& Jensen, A. (2012) Native oysters in Chichester harbour. Shellfish news, 34, 21-22.

Eagling, L.E. (2015) Developing best practice for native oyster, Ostrea edulis, production in a small regional fishery (PhD thesis). Queen's University Belfast, United Kingdom.

Eagling, L. E., Ashton, E. C. \& Eagle, J. (2015) The incentives of a resource owner: Evidence from a private oyster fishery, Marine Policy, 58, 28-35.

Ford, S. E., \& Figueras, A. J. (1988) Effects of sublethal infection by the parasite Haplosporidium nelson (MSX) on gametogenesis, spawning, and sex ratios of oysters in Delaware Bay, USA, Diseases of Aquatic Organisms, 4, 121-133.

Golding, N., Alman, S., \& Service, M., 2001. An acoustic benthic survey of Loch Ryan. Department of Agriculture and Rural Development, with Queen's University of Belfast report. 13 pages 
Helm, M. M., \& Bourne, N. (2004) Hatchery operation: broodstock conditioning, spawning and fertilization In. Lovatelli A., (ed. ) Hatchery culture of bivalves a practical manual, FAO fisheries technical paper 471, Rome

Howard, D. W., \& Smith, C. S. (1983) Histological techniques for marine bivalve molluscs: NOAA technical memorandum NMFS-F/NEC. 25. National Technical Information Service, Woods Hole. pp. 97

Hugh-Jones, T. (2011) Loch Ryan oyster beds: Our undervalued resource? International Conference of Shellfish Restoration, Stirling University August 2011.

Jenkins, G., Murphy, J., Sexton, D., Lowe, J., Jones, P., \& Kilsby, C., 2010. U. K. Climate Projections: Briefing report. U. K. Climate Projections. 10 pages

Joyce, A., Holthuis, T. D., Charrier, G., \& Lindegarth, S. (2013) Experimental effects of temperature and photoperiod on synchrony of gametogenesis and sex ratio in the European oyster Ostrea edulis (Linnaeus), Journal of Shellfish Research, 32, 447-458.

Kamphausen, L., Jensen, A., \& Hawkins, L. (2011) Unusually high proportion of males in a collapsing population of commercially fished oysters (Ostrea edulis) in the Solent, United Kingdom, Journal of Shellfish research, 30, 1-6

Kamphausen, L. (2012) The reproductive processes of a wild population of the European oyster Ostrea edulis in the Solent, UK, University of Southampton, School of Ocean and Earth Science, $\mathrm{PhD}$ Thesis 139 pages

Kennedy, V. S. (1983) Sex ratios in oysters, emphasizing Crassostrea virginica from Chesapeake Bay, Maryland, Veliger, 25, 329-339.

Laing, I., Walker, P., \& Areal, F. (2005) A feasibility study of native oyster (Ostrea edulis) stock regeneration in the United Kingdom. CARD Project FC1016. Native Oyster Stock 

DEFRA and Seafish.

Lane, D.E., and Stephenson, Robert, L. (1995) Fisheries management science: the framework to link biological, economic, and social objectives in fisheries management. Aquatic Living Resources, 8, 215-221

Loch Ryan Advisory Management Forum, 1999. Loch Ryan Strategy. Dumfries and Galloway Council

Loosanoff, V. L. (1962) Gametogenesis and Spawning of the European Oyster, O. edulis, in Waters of Maine. Biological Bulletin, 122, 86-94.

Mann, R. (1979) Some biochemical and physiological aspects of growth and gametogenesis in

Mather, A.S., 2003. Beaches of Southwest Scotland, Volume II. Department of Geography, University of Aberdeen, for the Countryside Commission for Scotland. Reprinted 2003 by

Meneghetti, F., Moschino, V., \& Da Ros, L., (2004) Gametogenic cycle and variations in oocyte size Conseil, 28, 432-439. 
Morishita, F., Furukawa, Y., Matsushima, O., \& Minakata, H. (2010) Regulatory actions of neuropeptides and peptide hormones on the reproduction of molluscs, Canadian Journal of Zoology, 88, 825-845.

Orton, J. H. (1927) Observation and Experiments on Sex-Change in the European Oyster (O. edulis): Part I. The Change from Female to Male. Journal of the Marine Biological Association of the United Kingdom, 14, 967-1045.

Orton, J. H. (1937) Oyster Biology and oyster-culture. Edward Arnold \& Co., London. 211 pp.

Orton, J. H. (1940) Effect of the severe frost of the winter of 1939-1940 on the Fauna of the Essex oyster beds, Nature, 145, 708-709.

OSPAR 2009. Background document for Ostrea edulis and Ostrea edulis beds. OSPAR Biodiversity Series 428/2009, 22pp

Park, K., Kim, R., Park, J. J., Shin, H. C., Lee, J. S., Cho, H. S., Lee, Y. G., Kim, J., \& Kwak, I. S. (2012) Ecotoxicological evaluation of tributyltin toxicity to the equilateral venus clam, Gomphina veneriformis (Bivalvia: Veneridae). Fish Shellfish Immunology, 32, 426-433.

Philippart, C. J., Amaral, A., Asmus, R., van Bleijswijk, J., Bremner, J., Buchholz, F., ... \& Comtet, T. (2012). Spatial synchronies in the seasonal occurrence of larvae of oysters (Crassostrea gigas) and mussels (Mytilus edulis/galloprovincialis) in European coastal waters. Estuarine, Coastal and Shelf Science, 108, 52-63.

R Core Team (2015) R: A language and environment for statistical computing. R Foundation for Statistical Computing, Vienna, Austria. URL http://www. R-project. org/.

Ruiz, C., Martinez, D., Mosquera, G., Abad, M., \& Sanchez, J. L. (1992) Seasonal variations in condition, reproductive activity and biochemical composition of the flat oyster, Ostrea edulis, from San Cibran (Galicia, Spain). Marine Biology, 112, 67-74. 
Santerre, C., Sourdaine, P., Marc, N., Mingant, C., Robert, R., \& Martinez, A. (2013) Oyster sex determination is influenced by temperature - First clues in spat during first gonadic differentiation and gametogenesis. Comparative Biochemistry and Physiology Part A: Molecular \& Integrative Physiology, 165, 61-69.

Syvret, M., Woolmer, A. \& Eagling, L. (2015) Ranching of the native oyster, Ostrea edulis, Restoration and Aquaculture Potential - Evaluation Report. For: The Mumbles Oyster Company Ltd., 52p.

Thain, J. E., \& Waldock, M. J. (1986) The impact of Tributyl Tin (TBT) Antifouling paints on molluscan fisheries. Water Science and Technology, 18, 193-202.

Thomas, Y., Pouvreau, S., Alunno-Bruscia, M., Barillé, L., Gohin, F., Bryere, P., \& Gernez, P. (2015). Global change and climate-driven invasion of the Pacific oyster (Crassostrea gigas) along European coasts: a bioenergetics modelling approach. Journal of Biogeography, 43, 568579.

UKBG, 1999. Tranche 2 Action Plans: Maritime Species and Habitats. Biodiversity Action Plans. United Kingdom Biodiversity Group

University Marine Biological Station Millport (2007) Conservation of the Native Oyster Ostrea edulis in Scotland. Scottish Natural Heritage Commissioned Report No. 251 (ROAME No. F02AA408).

Walne, P. R. (1974) Culture of Bivalve Molluscs 50 years' experience at Conwy, Fishing News (Books) Limited, The Whitefrairs Press Itd, London and Tonbridge

Wilson, J. H., \& Simons, J. (1985) Gametogenesis and breeding of Ostrea edulis on the west coast of Ireland, Aquaculture, 46, 307-321. 
523 Winemiller, K. O. (2005) Life history strategies, population regulation, and implications for fisheries management. Canadian Journal of Fisheries and Aquatic Science, 62, 872-885.

525 
Table 1. Monthly number of male, female and undetermined oysters observed, monthly sex ratio, results of Chi squared tests comparing monthly/total sex ratio to 1:1, for both the summer of 2013 and 2014 in Loch Ryan, Scotland.

\begin{tabular}{llllll}
\hline Month & Male & Female & Undetermined & $\begin{array}{l}\text { Male: } \\
\text { Female }\end{array}$ & $\begin{array}{l}\text { Chi squared test } \\
\text { compared to 1:1 } \\
\left(\chi^{2}, \mathrm{df}, \mathrm{p}\right)\end{array}$ \\
\hline April & 3 & 3 & 1 & $1: 1$ & $0,1, \mathrm{NS}$ \\
May & $\mathrm{N} / \mathrm{A}$ & $\mathrm{N} / \mathrm{A}$ & & $\mathrm{N} / \mathrm{A}$ & $\mathrm{N} / \mathrm{A}$ \\
June & 23 & 5 & 5 & $4.6: 1$ & $11.57,1,<0.001$ \\
July & 10 & 7 & 4 & $1.5: 1$ & $0.53,1, \mathrm{NS}$ \\
August & 23 & 14 & 3 & $1.6: 1$ & $2.19,1, \mathrm{NS}$ \\
September & 14 & 19 & 7 & $0.7: 1$ & $0.76,1, \mathrm{NS}$ \\
October & 14 & 6 & 15 & $2.3: 1$ & $3.2,1, \mathrm{NS}$ \\
\hline Total 2013 & 87 & 54 & 35 & $1.5: 1$ & $7.72,1,<0.01$ \\
\hline April & 6 & 10 & & $0.6: 1$ & $0.6,1, \mathrm{NS}$ \\
May & 24 & 13 & 3 & $1.8: 1$ & $3.2,1, \mathrm{NS}$ \\
June & 10 & 9 & 1 & $1.1: 1$ & $0.05,1, \mathrm{NS}$ \\
July & 23 & 15 & 1 & $1.5: 1$ & $1.68,1, \mathrm{NS}$ \\
August & 14 & 4 & 3 & $3.5: 1$ & $14.24,1,<0.001$ \\
September & 47 & 10 & 2 & $4.7: 1$ & $19.88,1,<0.001$ \\
October & 11 & 7 & 22 & $1.6: 1$ & $0.4,1, \mathrm{NS}$ \\
\hline Total 2014 & 135 & 68 & 32 & $2: 1$ & $26.96,1,<0.001$ \\
\hline Total & 222 & 122 & 67 & $1.8: 1$ & $29.07,1,<0.001$ \\
\hline
\end{tabular}


536

Table 2. Monthly percentage of male and female oysters observed, monthly sex ratio, results of Chi squared tests comparing monthly sex ratio to 1:1 for both the summer of 1960 and 1961 in Loch Ryan, Scotland (Adapted from Millar, 1964)

\begin{tabular}{lcccc}
\hline Date & \% Male & \% Female & Male: Female & $\begin{array}{c}\text { Chi squared test } \\
\text { compared to } 1: 1 \\
\left(\chi^{2}, \mathrm{df}, \mathrm{p}\right)\end{array}$ \\
\hline $03 / 05 / 1960$ & 64 & 36 & $1.77: 1$ & $7.84,1,<0.01$ \\
$06 / 06 / 1960$ & 60 & 40 & $1.5: 1$ & $4,1, \mathrm{NS}$ \\
$27 / 06 / 1960$ & 71 & 29 & $2.45: 1$ & $17.64,1,<0.001$ \\
$23 / 07 / 1960$ & 74 & 20 & $3.7: 1$ & $31,1,<0.001$ \\
$15 / 08 / 1960$ & 52 & 12 & $4.33: 1$ & $25,1,<0.001$ \\
$02 / 10 / 1960$ & 21 & 17 & $1.24: 1$ & $0.42,1, \mathrm{NS}$ \\
$17 / 12 / 1960$ & 7 & 27 & $0.26: 1$ & $11.7,1,<0.001$ \\
\hline $25 / 03 / 1961$ & 24 & 35 & $0.69: 1$ & $1.7,1, \mathrm{NS}$ \\
$03 / 05 / 1961$ & 58 & 40 & $1.45: 1$ & $3.3,1, \mathrm{NS}$ \\
$31 / 05 / 1961$ & 68 & 31 & $2.19: 1$ & $12.96,1,<0.001$ \\
$23 / 06 / 1961$ & 66 & 34 & $1.94: 1$ & $10.24,1,<0.01$ \\
$30 / 06 / 1961$ & 66 & 34 & $1.94: 1$ & $10.24,1,<0.01$ \\
$10 / 07 / 1961$ & 66 & 19 & $3.47: 1$ & $24.6,1,<0.001$ \\
$21 / 07 / 1961$ & 56 & 25 & $2.24: 1$ & $10.97,1,<0.001$ \\
$05 / 08 / 1961$ & 53 & 28 & $1.89: 1$ & $7.2,1, \mathrm{NS}$ \\
$17 / 08 / 1961$ & 66 & 19 & $3.47: 1$ & $24.6,1,<0.001$ \\
$22 / 08 / 1961$ & 64 & 9 & $7.11: 1$ & $43.5,1,<0.001$ \\
$26 / 08 / 1961$ & 43 & 11 & $3.91: 1$ & $18.9,1,<0.001$ \\
\hline
\end{tabular}


539 Table 3. Chi squared test results comparing annual variation within Loch Ryan. As results were not significantly different these data were then pooled and the ratio tested against Southampton

(Kamphausen et al., 2011), Chichester and Greek populations (da Silva et al., 2009).

\begin{tabular}{|c|c|c|c|}
\hline Test population & $\begin{array}{l}\text { Male: } \\
\text { Female }\end{array}$ & $\begin{array}{l}\text { Chi squared } \\
\text { compared to Loch } \\
\text { Ryan }\left(\chi^{2}, d f, p\right)\end{array}$ & $\begin{array}{l}\text { Chi squared } \\
\text { compared to } 1: 1 \\
\left(\chi^{2}, d f, p\right)\end{array}$ \\
\hline Loch Ryan 2013 - 2014 & $3: 2$ to $2: 1$ & $1.9,1, \mathrm{NS}$ & N/A \\
\hline Southampton & $6: 1$ & $39.6,1,<0.001$ & $71.43,1,<0.001$ \\
\hline Chichester & $3: 1$ & $5.9,1,<0.05$ & $47.64,1,<0.001$ \\
\hline Greek cohort & $3: 1$ & $5.9,1,<0.05$ & $47.64,1,<0.001$ \\
\hline
\end{tabular}


Figure Legends

Figure 1. Map of the United Kingdom and Ireland, black dots indicate the location of the study sites. Adapted from Eagling, Ashton \& Eagle, 2015.

Figure 2. Ostrea edulis gonad index showing; Early development male (A) and female (B), Late development male (C) and female (D), Early maturation male $(E)$ and female $(F)$, Ripe male (G) and female $(\mathrm{H})$, Partially spent male $(\mathrm{I})$ and female $(\mathrm{J})$, Spent male $(\mathrm{K})$, Inactive $(\mathrm{L})$ all at $20 \mathrm{x}$ magnification.

Figure 3. Average daily temperature from Loch Ryan, Scotland in 1960, 1961, 2013, 2014 and Chichester Harbour, England 2011

Figure 4. Gametogenic progression during the breeding period for Loch Ryan, Scotland oysters over 2013 (A) and 2014 (B), and Chichester Harbour, England 2011 (C)

Figure 5. Seasonal changes in sex ratio expressed as percentages of males (black) and females (grey) overlaid with daily average temperature for Loch Ryan, Scotland in (A) 1960 (B) 1961, (C) 2013, (D) 2014 and (E) Chichester Harbour, England in 2011. * represent sex ratios significantly skewed from a $1: 1$ ratio. Black line indicates predicted threshold temperature $16.5^{\circ} \mathrm{C}$ in Loch Ryan and $17.5^{\circ} \mathrm{C}$ in Chichester Harbour

Figure 6. Seasonal changes in the percentage (of all oysters sampled) of oysters brooding for Loch Ryan, Scotland in (A) 1960, (B) 1961, (C) 2013, (D) 2014 and (E) Chichester Harbour, England in 2011. Solid line - Mean annual brooding percentage, Dashed lines - standard error

Figure 7. Proportion of males (A) and females brooding (B) in relation to average monthly temperature at each sampling interval for Loch Ryan, Scotland 2013/14 and Chichester Harbour, England 2011. (C) Relationship between brood size for Ostrea edulis in 2013 \& 2014 from Loch Ryan, Scotland and average daily temperature, and (D) Relationship between the proportions of females brooding and males at each sampling interval for Loch Ryan, Scotland 2013/14 and Chichester Harbour, England 2011 